\title{
The distribution of estuarine fish larvae: Nutritional condition and co-occurrence with predators and prey
}

\author{
Eduardo Esteves*, Teresa Pina , M. Alexandra Chícharo, J. Pedro Andrade \\ CCMar - UCTRA Universidade do Algarve, Campus de Gambelas, 8000-810 Faro, Portugal. \\ * Corresponding author (fax: +35189818353; e-mail: eesteves@ualg.pt)
}

Received 25 January 2000; revised 1 May 2000; accepted 25 May 2000

\begin{abstract}
Fish larvae were collected monthly between March and September 1997 in the Mira and Guadiana estuaries (southern Portugal). Hydrological parameters were registered and zooplankton samples were obtained simultaneously. Densities of fish larvae (ind $100 \mathrm{~m}^{-3}$ ) were calculated from 211 samples and larval nutritional condition measured as RNA/DNA ratios were obtained for 346 individuals, using a fluorimetric method for nucleic acid quantification. Correlating variables were further studied using multiple regression analysis in order to assess the relative importance of abiotic and biotic factors affecting within-year trends in abundance and nutritional condition of estuarine fish larvae. Results indicated that: 1) the abundance of fish larvae seems conditioned by temperature and predation; and 2) their nutritional condition is dependent on temperature and prey availability. Temperature is an important variable structuring estuaries and therefore conditions the behaviour and physiology of fish larvae. Furthermore, the co-occurrence of predators and larvae might be related to similar feeding patterns or comensalism. Whenever feeding conditions are suitable, they usually determine enhanced growth and nutritional condition. However, predation seems to control this latter relationship through its effect on larval mortality. (C) 2000 Éditions scientifiques et médicales Elsevier SAS
\end{abstract}

Fish larvae / distribution / RNA/DNA ratios / nutritional condition

\section{INTRODUCTION}

Recruitment to commercial or adult stocks of fish is believed to depend primarily on survival during the annual re-colonisation of the environment by larval stages [39]. Several hypotheses linking abiotic and biotic factors with larval mortality have been presented [20, 33, 34, 43, 66]. However, it is not generally agreed whether density-independent (temperature, advection) or density-dependent mechanisms (starvation, predation) prevail in determining the survival of larvae. Although hydrological factors and predation seem to regulate larval mortality [3], starvation is also responsible, directly or through increasing vulnerability to predation and liability to detrimental abiotic factors [37].

Since Bulow [10] first stated the usefulness of nucleic acid-based indices for nutritional condition

\footnotetext{
$\S$ Present address: IPIMAR, Av. 5 Outubro, 8700-305 Olhão, Portugal.
}

analysis of marine fish larvae, several authors have used RNA/DNA ratios for the assessment of condition and growth of larvae (see [6] for a review). The RNA/DNA ratio is an ecophysiological index of condition, which reflects the potential for protein synthesis [17]. The use of nucleic acid-based indices, e.g. RNA/DNA ratios, allows the study of larval nutritional condition and its relationship with several abiotic and biotic factors and their relative importance in determining larval mortality and recruitment.

Clupeidae, Gobiidae, Blennidae and Atherinidae larvae are among the most common and representative families of fish in Portuguese estuaries (e.g. [16, 21]). Clupeids are a basic component of an important pelagic fishery off the Atlantic coast of the Iberian Peninsula [55] and the other three families are described as resident species of a number of estuaries [1, $16,47,59,60]$.

Quantitative assessment of the relative importance of abiotic and biotic factors is lacking for most Portuguese estuaries. Hence, the aim of this study was to examine how short-term changes in temperature, 
salinity, turbidity, and abundance of potential prey and predators affect within-year trends in the abundance, distribution and nutritional condition of fish larvae in the Mira and Guadiana estuaries (Portugal).

\section{MATERIALS AND METHODS}

\subsection{Study areas}

The Mira and Guadiana located in southern Portugal (figure 1) are partially mixed estuaries (see [42] for a review). In the Mira, the influence of the tide extends to Odemira (figure 1, station \#7), approximately $30 \mathrm{~km}$ from the mouth, where mechanical effects are evident and salinity ranges from $<0.5$ to 6.0 PSU. In the Guadiana, the salinity effects $(<0.5-2.0 \mathrm{PSU})$ and mechanical effects of the tide extend to Mértola (figure 1, station \#6), more than $60 \mathrm{~km}$ away from the mouth. In addition, average monthly river discharge does not exceed $4 \cdot 10^{6} \mathrm{~m}^{3}$ in the Mira (in April) whereas in the Guadiana, it varies between $39 \cdot 10^{6} \mathrm{~m}^{3}$ (in July) and $170 \cdot 10^{6} \mathrm{~m}^{3}$ (in May) [SNIRH, http://set.inag.pt/snirh/].

\subsection{Larval sampling and hydrological measurements}

Between March and September 1997, fish larvae were sampled monthly in fifteen stations located in the Mira $(n=8)$ and Guadiana $(n=7)$ estuaries (figure 1$)$. The stations covered the major regions of the estuaries, from the euhaline zone to the oligohaline/limnetic transition area, sensu Mc Gurk et al. [48]. Temperature, salinity, Secchii disk depth and zooplankton samples were recorded simultaneously. In May, June, July and September, samples were also collected every $2 \mathrm{~h}$ during four 24-h sampling at Vila Nova de Milfontes (Mira river) and Vila Real Santo de António (Guadiana river) - in both cases near the river mouth (figure 1).

Mesozooplankton was collected with a conical net $(0.37 \times 1.60 \mathrm{~m}, 0.5-\mathrm{mm}$ mesh size $)$ towed at $1 \mathrm{~m}$ depth, at a constant speed of approximately $1 \mathrm{~m} \cdot \mathrm{s}^{-1}$ for $10 \mathrm{~min}$. Samples were sorted in a black glass tray, the fish larvae retrieved and immediately frozen in liquid nitrogen $\left(-197^{\circ} \mathrm{C}\right)$. The remaining zooplankters were stored in buffered $4 \%$ formaldehyde solution. A further $10 \mathrm{~L}$ water were sampled at $0.5 \mathrm{~m}$ depth and filtered through a $0.06-\mathrm{mm}$ mesh size net to collect microzooplankters. During larval fish and zooplankton sampling, Secchii disk depth was monitored and surface temperature $\left({ }^{\circ} \mathrm{C}\right)$ and salinity (PSU) were measured using a thermometer and a refractometer, respectively.
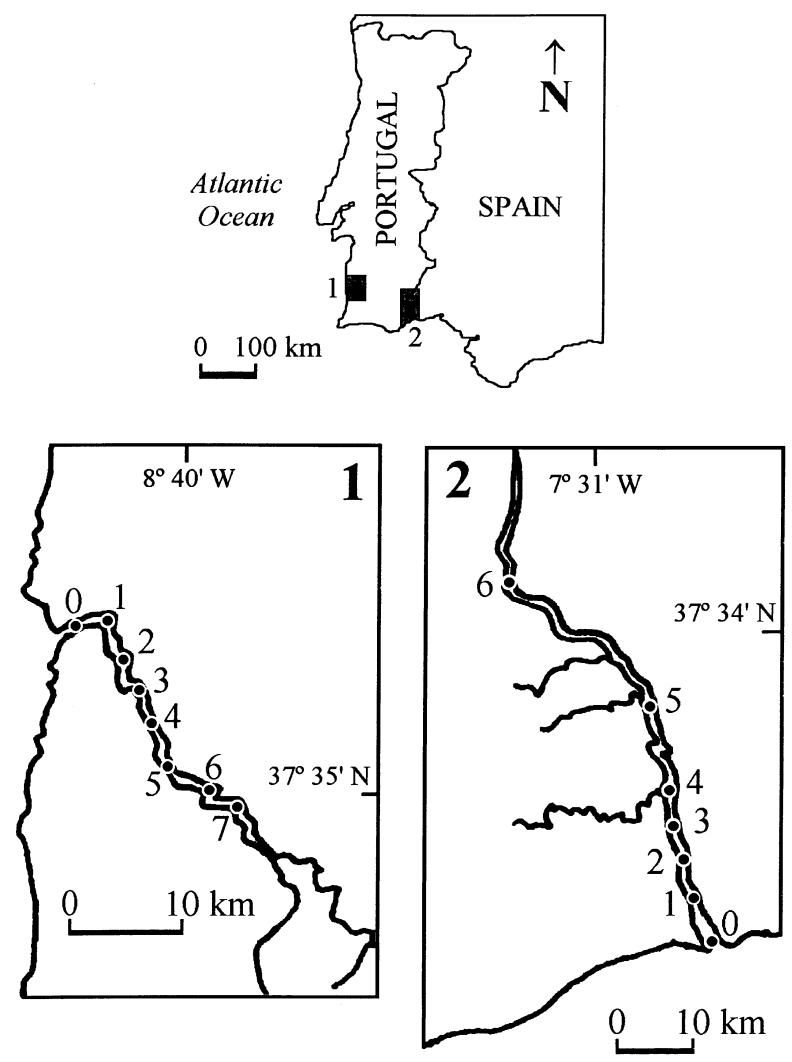

Figure 1. Rivers Mira and Guadiana (south Portugal) showing the sampling locations (denoted by $\mathbf{0}$ ).

\subsection{Laboratory procedures and larval condition analyses}

Fish larvae and the remaining preserved zooplankters were identified using keys provided in Fives [28], Newell and Newell [50], Palmer and Culley [52], Russell [62], Saville [63], Smith [68], and Todd and Laverack [75]. Fish larvae were identified to family level in order to minimise taxonomical errors and include the least represented species [64]. Larvae of Clupeidae, Blennidae, Gobiidae and Atherinidae each accounted for more than $10 \%$ of total ichthyoplankton abundance and were used for further analyses. Whenever zooplankters were extremely abundant, successive sub-samples obtained with a 2-mL Stemple-type pipette (microzooplankters) and a Folsom splitter (mesozooplankters) were analysed and at least 300 organisms counted [51]. Density was expressed as number of individuals $\cdot 100 \mathrm{~m}^{-3}$.

For the analyses of nutritional condition, individually frozen larvae $(n=346)$ were thawed, identified and measured (to the nearest $0.1 \mathrm{~mm}$ ). Nutritional condition was assessed using the RNA/DNA ratio. 
Nucleic acids in individual fish larvae were quantified according to a modified procedure from Caldarone and Buckley's [13] fluorimetric method and using ethidium bromide as the fluorophor (see [26] for protocol details).

\subsection{Data analyses}

Spearman rank correlation analysis [19] was used to identify relevant variables for subsequent analyses. Non-parametric correlation analyses do not presume that variables are normally distributed or assume any particular type of relationship between variables. The significance of $r$ was corrected using the method of Bonferroni [69].

The relationships between larval density or nutritional condition and selected variables were studied using multiple regression analysis (forward stepwise method) [70]. For each estuary, data on the spatial and diel variation of larval nutritional condition was pooled in order to increase sample number. The significance of the calculated empirical models was assessed considering the coefficient of determination, partial coefficients of correlation and ANOVA results [79]. All the analyses were performed using SPSS ${ }^{\circledR}$ software package [70].

\section{RESULTS}

Surface temperature decreased steadily seaward from $27{ }^{\circ} \mathrm{C}$ at the upriver stations to about $15.5^{\circ} \mathrm{C}$ (river Mira) and $13.9^{\circ} \mathrm{C}$ (river Guadiana) near the river mouth. Conversely, salinity (0.6-37.4 PSU) (figure 2) and Secchii depth $(0.25-2.70 \mathrm{~m})$ increased regularly towards stations \#0.

\subsection{Larval and zooplankton abundance}

Densities of fish larvae during the day did not exceed 40 ind $\cdot 100 \mathrm{~m}^{-3}$, whereas values obtained during diel collections were higher, particularly in the Guadiana. Density maxima of about 45 and 85 ind $100 \mathrm{~m}^{-3}$ were estimated for clupeids in the Mira and Guadiana, respectively. Gobiidae and Blennidae larvae were irregularly more abundant with maximum densities $>300$ ind $\cdot 100 \mathrm{~m}^{-3}$. Estimated densities varied greatly between sampling stations and rivers, sometimes by two orders of magnitude (table I). In both rivers, microzooplankton consisted almost entirely of crustacean nauplii (often representing $>80 \%$ of sample abundance), copepodites (8-27\%), and bivalve (7.5-32\%) and gastropod larvae (3-12\%) (table II). Diel sampling revealed contrasting microzooplanktonic composition between the estuaries. Bivalve larvae, copepod nauplii and copepodites were
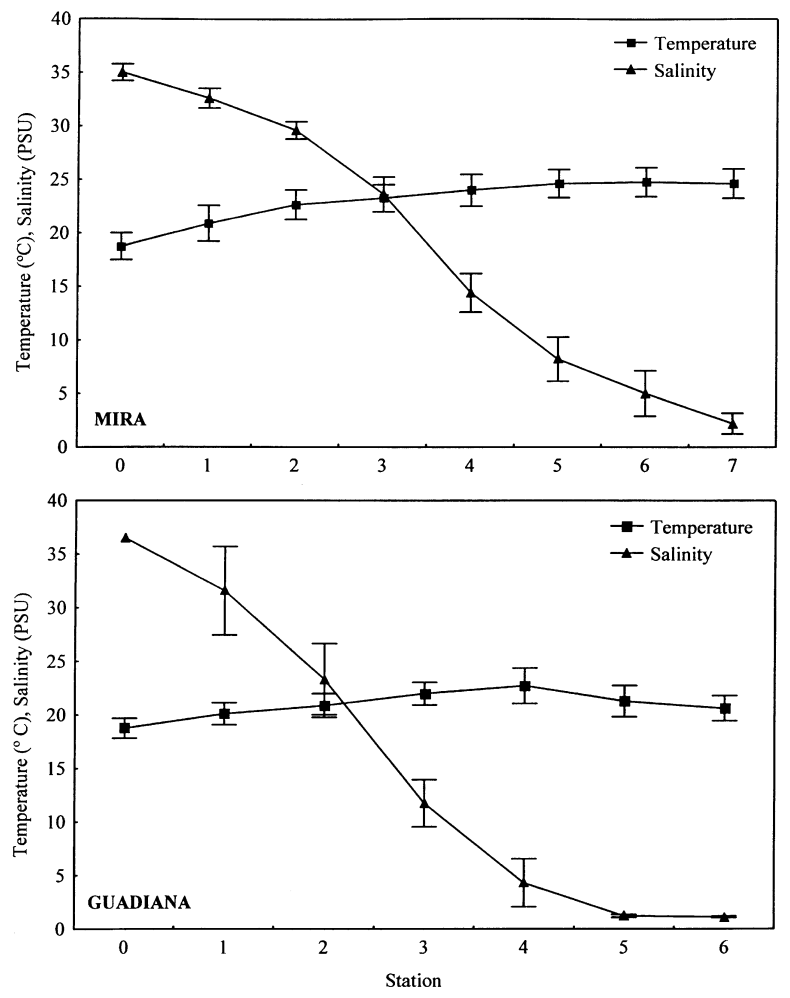

Figure 2. Spatial variation of surface temperature $\left({ }^{\circ} \mathrm{C}\right)$ and salinity (PSU) measured between March and September 1997 (mean \pm SE, $n \geq 7$ ).

the most abundant taxa in the Mira (>83\% of total abundance), while in the Guadiana copepod nauplii and gastropod larvae accounted for $81 \%$ of total abundance (table II). The composition of mesozooplanktonsamples was different between estuaries. In the Mira, mysids, decapods (zoea/mysis) and copepodscommonly represented about $5-40 \%$ of sample abundance. Decapods and copepods were relatively more abundant during diel sampling. Conversely, hydromedusae represented about $40 \%$ of daytime sample abundance and mysids were ten times more abundant in samples obtained during the day (table II). In the Guadiana, copepods, cladocerans and decapods (zoea/mysis) were the most abundant taxa. Copepods represented about $60 \%$ of daytime sample abundance (ten times more abundant than in diel collections). Conversely, decapods (zoea/mysis) and cladocerans were more abundant during diel sampling (22 vs. $15 \%$ ). Mysids, decapod nauplii and chaetognats represented each less than $10 \%$ of total abundance (table II).

Clupeidae and Gobiidae larvae were more abundant near the mouth. In contrast, blennids occurred in higher densities in the upper reaches of the estuary 
Table I. Density of fish larvae (individuals $100 \mathrm{~m}^{-3}$ ) in the Mira and Guadiana estuaries (March-September 1997). $n$, Number of stations/samples in which larvae occurred. S and D denote spatial and diel sampling, respectively.

\begin{tabular}{|c|c|c|c|c|c|c|c|c|}
\hline \multicolumn{5}{|c|}{ Mira } & \multicolumn{4}{|c|}{ Guadiana } \\
\hline & $n_{\mathrm{S}}$ & Range & $n_{\mathrm{D}}$ & Range & $n_{\mathrm{S}}$ & Range & $n_{\mathrm{D}}$ & Range \\
\hline Clupeidae & 7 & $2.1-33.3$ & 18 & $1.4-44.4$ & & & 20 & $1.8-85.2$ \\
\hline Gobiidae & 9 & $1.2-40.7$ & 23 & $1.9-96.1$ & 7 & $2.6-32.7$ & 31 & $1.6-324.2$ \\
\hline Blennida & 12 & $1.1-10.5$ & 12 & $1.8-310.4$ & 2 & $1.4-7.1$ & 23 & $1.6-324.2$ \\
\hline Atherinidae & 3 & $2.6-4.8$ & 10 & $1.5-35.9$ & 1 & & 9 & $1.8-4.7$ \\
\hline
\end{tabular}

$\left(<10\right.$ larvae $\left.\cdot 100 \mathrm{~m}^{-3}\right)$ whereas atherinids were collected infrequently (less than ten occurrences throughout the study period) (figure 3). Fish larvae were relatively more abundant during the night, particularly the gobiids and blennids which were collected in higher numbers at dawn and dusk (figure 4). The distributions of fish larvae and their potential prey were seldom in counter-phase (figure 5), i.e. higher values of fish larvae corresponded to minima of potential prey abundance (figure 6, upper panel). In contrast, predators and larval fish distributions were frequently similar. This was particularly evident for gobiids-apendicularians (figure 5, upper panel) and clupeids-apendicularians/mysids (figure 6).

Table II. Percentage of total abundance of taxa occurring in the zooplankton samples collected in the Mira and Guadiana rivers (MarchSeptember 1997).

\begin{tabular}{|c|c|c|c|c|}
\hline & Mira & & Guadiana & \\
\hline \multicolumn{5}{|l|}{ Microzooplankton: } \\
\hline \multirow[t]{4}{*}{ Spatial sampling } & Copepoda nauplii & $>86 \%$ & Copepoda nauplii & $>80 \%$ \\
\hline & Gastropoda larvae & $3 \%$ & Copepodites & $8 \%$ \\
\hline & Foraminifera & $3 \%$ & Ciliata & $7 \%$ \\
\hline & Dinoflagellata & $3 \%$ & Rotifera & $2 \%$ \\
\hline \multirow[t]{6}{*}{ Diel sampling } & Bivalve larvae & $32 \%$ & Copepoda nauplii & $69 \%$ \\
\hline & Copepodites & $27 \%$ & Gastropoda larvae & $12 \%$ \\
\hline & Copepoda nauplii & $24 \%$ & Anelida larvae & $7.5 \%$ \\
\hline & Anelida larvae & $10 \%$ & Bivalve larvae & $7.5 \%$ \\
\hline & Hidrozoa & $3 \%$ & & \\
\hline & Gastropoda larvae & $2 \%$ & & \\
\hline \multicolumn{5}{|l|}{ Mesozooplankton: } \\
\hline \multirow[t]{6}{*}{ Spatial sampling } & Hydromedusae & $44 \%$ & Copepoda & $57 \%$ \\
\hline & Mysidacea & $32 \%$ & Cladocera & $14 \%$ \\
\hline & Decapoda zoea/mysis & $8 \%$ & Decapoda nauplii & $8 \%$ \\
\hline & Decapoda nauplii & $5 \%$ & Insecta & $3 \%$ \\
\hline & Copepoda & $5 \%$ & Decapoda zoea/mysis & $4 \%$ \\
\hline & & & Chaetognata & $3 \%$ \\
\hline \multirow[t]{8}{*}{ Diel sampling } & Decapoda nauplii & $45 \%$ & Cladocera & $22 \%$ \\
\hline & Copepoda & $20 \%$ & Decapoda zoea/mysis & $15 \%$ \\
\hline & Decapoda zoea/mysis & $16 \%$ & Mysidacea & $8 \%$ \\
\hline & Cladocera & $6 \%$ & Copepoda & $4 \%$ \\
\hline & Mysidacea & $3 \%$ & Hydrozoa & $2 \%$ \\
\hline & Thaliacea & $2 \%$ & Chaetognata & $1 \%$ \\
\hline & Apendicularia & $1.7 \%$ & & \\
\hline & Isopoda & $1.5 \%$ & & \\
\hline
\end{tabular}



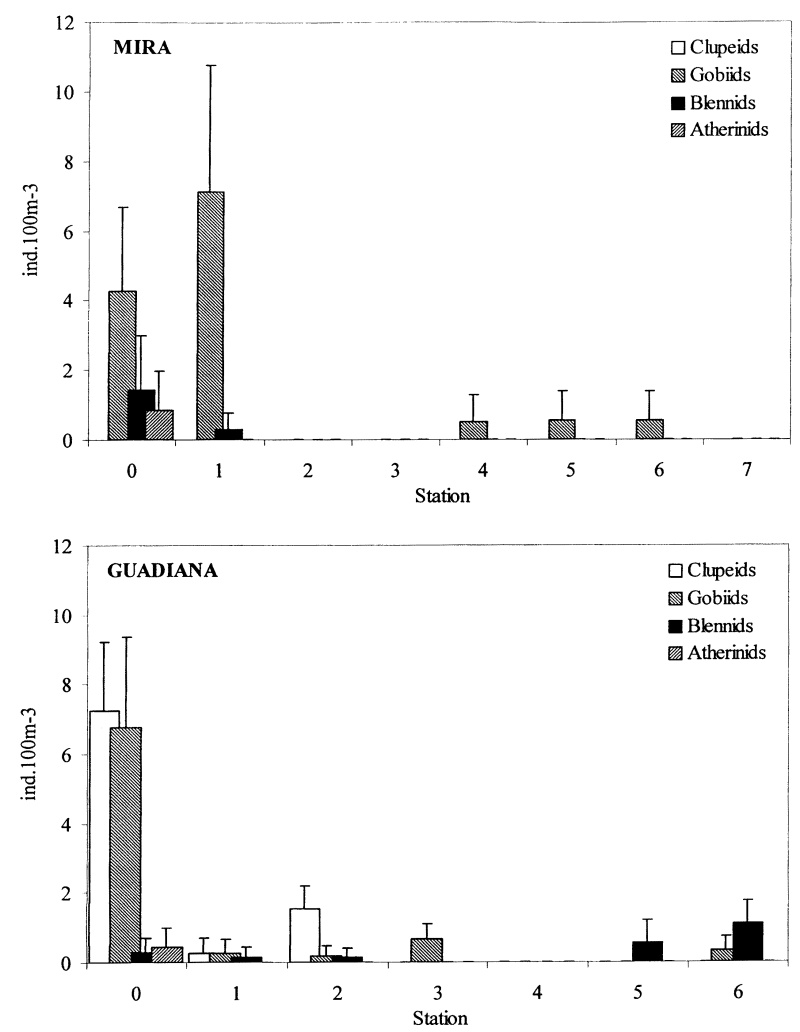

Figure 3. Spatial changes in density of fish larvae in the rivers Mira and Guadiana (mean \pm SE, $n=8$ and 7 , respectively).

Larval densities were significantly correlated $(P<0.001)$ with temperature and the abundance of several taxa of potential prey and predators. Significant correlation coefficients varied between -0.57 (gobiids-temperature) and 0.73 (clupeidscladocerans), with most values within the range 0.40-0.60 (table III). The abundance distribution of clupeids was related to isopods, apendicularians, cladocerans and chaetognats, and gobiids were correlated with temperature, apendicularians and cumaceans (figure 7). Most of the models included two or more independent variables and accounted for about 53 to $98 \%$ of the variance of larval density, except the one describing clupeid abundance in the Guadiana, which only explained $31.5 \%$ of the variance (table IV).

\subsection{Larval condition}

Mean RNA/DNA ratios varied between $2.98 \pm 0.36$ (mean \pm standard error) for Blennidae in river Mira and $8.15 \pm 0.65$ for Clupeidae in river Guadiana. Generally, values of the ratio averaged 3.5-5.5 ( $\mathrm{ta}$ ble $V)$. RNA/DNA ratios correlated significantly $(P<0.001)$ with the abundance of several taxa of
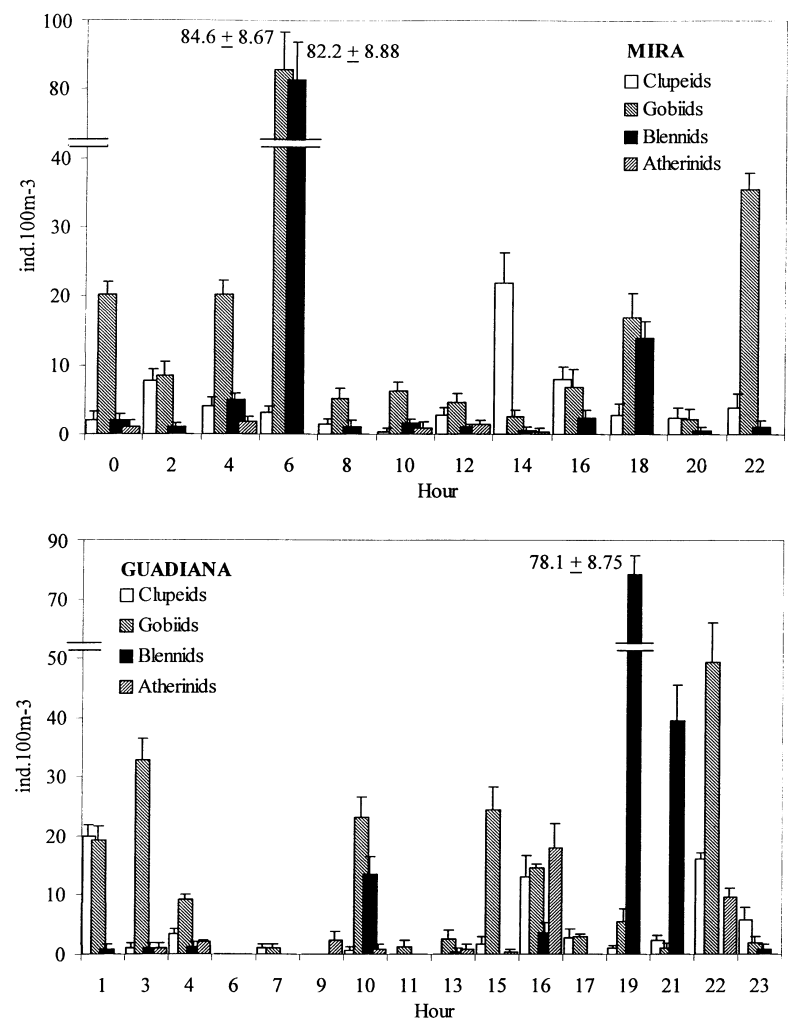

Figure 4. Diel variation of fish larvae at Vila Nova de Milfontes (river Mira) and at Vila Real Santo António (river Guadiana). Pooled data from four 24-h sampling periods (mean \pm SE, $n=4$ ).

potential prey $(-0.46<r<0.55)$ and particularly with the abundance of predators/competitors $(0.39<$ $r<0.70)$. Significant correlation coefficients varied between -0.46 (blennids-decapod nauplii) and 0.70 (clupeids-mysids) (table VI). Nevertheless, temperature and the abundance of potential prey, namely dinoflagellates, crustacean nauplii, copepodites and bivalve larvae, constituted the majority of the independent variables included in the empirical models obtained using stepwise forward regression methods. Models explained about $43.1-95.5 \%$ of the variance of RNA/DNA (figure 8). Values of $R^{2}$ obtained were higher for models calculated from data collected in the Mira $\left(R^{2} \geq 0.732\right)$ than for the Guadiana $\left(R^{2} \geq 0.431\right)$ (table VII).

\section{DISCUSSION}

\subsection{Zooplankton abundance}

This study indicated that temperature and salinity were important in determining larval abundance. Tem- 

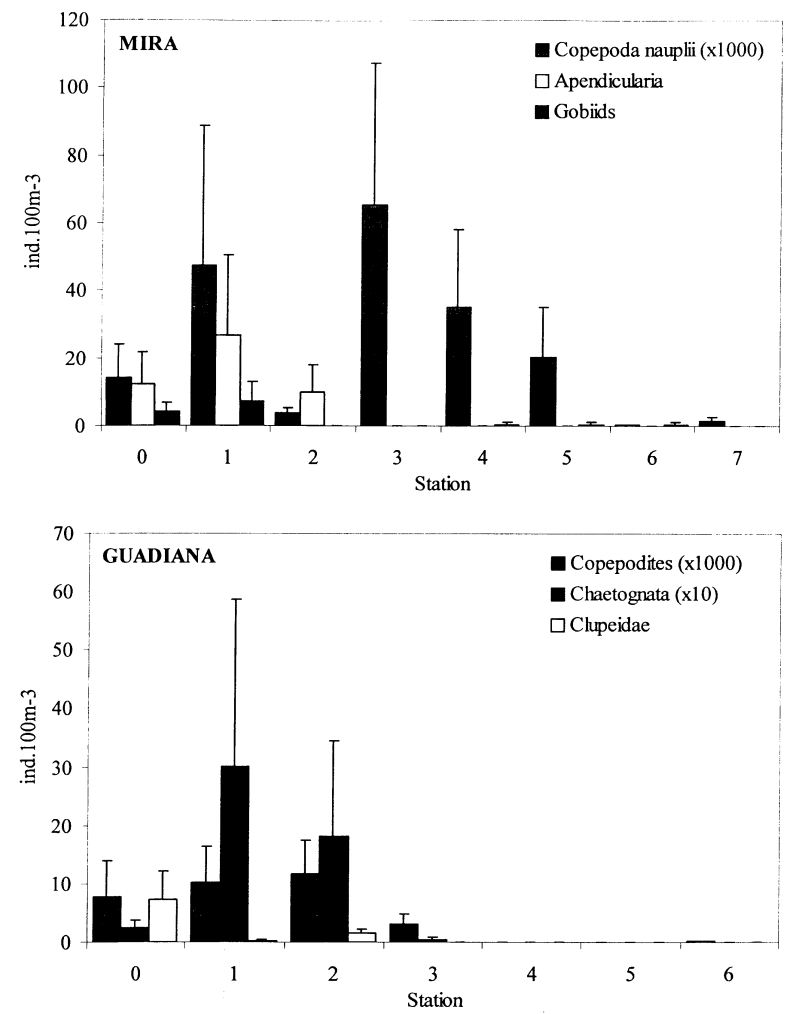

Figure 5. Spatial variation in density of fish larvae and relevant planktonic taxa (potential prey and predators) in the rivers Mira and Guadiana (mean \pm SE, $n=8$ and 7 respectively).

perature and salinity are structuring variables of estuaries [4, 74], establishing habitats and conditioning the behaviour of organisms, including the meroplanktonic fish larvae. Moreover, temperature has been linked to larval mortality [32], to larvae ecology [76], to the reproductive cycle of adults and spawning [35, 53], and to cycles of primary and secondary production of plankton [12]. Furthermore, the results presented herein are in agreement with those of Crecco and Savoy [23, 24], Robinson and Bain [61], Turner et al. [76] and Thiel et al. [74]. These authors also reported significant correlations between several abiotic parameters, namely water temperature, salinity and flow, and larval abundance.

In both the Mira and Guadiana estuaries, larval abundance correlated significantly with the abundance of taxa described in the literature as potential prey, namely crustacean nauplii, copepodites and bivalve or gastropod larvae [40]. The positive correlations could result from the active search by fish larvae for patches of prey [39]. In fact, when present in patches of food, larvae tend to reduce swimming activity thus remaining within the aggregation, which corresponds to
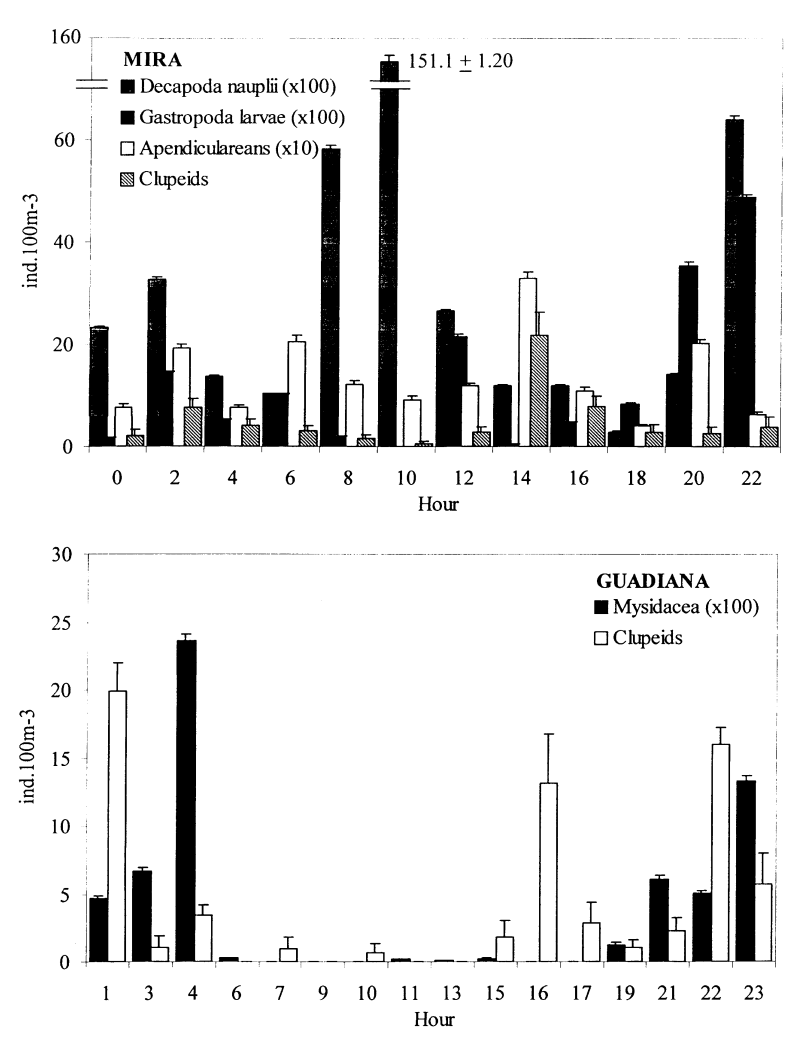

Figure 6. Diel changes in density of clupeids and relevant prey and predator taxa at Vila Nova de Milfontes (river Mira) and Vila Real de Santo António (river Guadiana). Pooled data from four 24-h sampling periods (mean $\pm \mathrm{SE}, n=4$ ).

area-restricted foraging [41, 78]. Also, fish larvae only perceive food items at a relatively short distance, less than one larval length for clupeids [7], and search less than $10 \mathrm{~L} \cdot \mathrm{d}^{-1}$ [36]. Hence, the presence of fish larvae in patches of potential prey, depicted by the positive correlations obtained herein, might increase the encounter probability and, therefore, enhance feeding success [44]. The spatial and diel distribution of fish larvae observed in this study is probably related to vertical and/or horizontal displacements as a function of potential prey. Fish larvae tend to aggregate at certain depths where food concentration is higher [29]. Sinclair and Iles [67] and Taggart and Leggett [73] reported independent spatial and temporal distributions of Clupea harengus and Mallotus villosus larvae and their planktonic prey. In contrast, DeVries and Stein [25] and Stein et al. [71] observed coincident distributions of larval Dorossoma cepedianum and zooplankton. Recently, Hugie and Dill [38] developed a model of habitat selection and found that fish larvae (acting as predators) tend to be distributed as a function of productivity instead of prey abundance. 
Table III. Significant Spearman correlation coefficients $(r)$ obtained for the relationships between ichthyoplankter abundance and several variables. (All $r$ have $P<0.001$ except $^{\text {a }}$ where $P<0.05$ ).

\begin{tabular}{|c|c|c|c|c|}
\hline \multirow[t]{2}{*}{ River } & \multirow{2}{*}{$\begin{array}{l}\text { Spatial sampling } \\
\text { Relationship }\end{array}$} & \multicolumn{3}{|c|}{ Diel sampling } \\
\hline & & $r$ & Relationship & $r$ \\
\hline \multirow[t]{11}{*}{ Mira } & Gobiidae-Temperature & -0.57 & Clupeidae-Temperature & -0.55 \\
\hline & Gobiidae-Apendicularia & 0.53 & $\begin{array}{l}\text { Clupeidae-Cirripedia nau- } \\
\text { plii }\end{array}$ & 0.47 \\
\hline & Blennidae-Chaetognata & 0.50 & Clupeidae-copepodites & 0.55 \\
\hline & & & $\begin{array}{l}\text { Clupeidae-Gastropoda lar- } \\
\text { vae }\end{array}$ & -0.46 \\
\hline & & & $\begin{array}{l}\text { Clupeidae-Pelecypoda lar- } \\
\text { vae }\end{array}$ & 0.44 \\
\hline & & & Clupeidae-Cladocera & 0.73 \\
\hline & & & Clupeidae-Copepoda & 0.53 \\
\hline & & & Clupeidae-Isopoda & $0.38^{\mathrm{a}}$ \\
\hline & & & $\begin{array}{l}\text { Clupeidae-Decapoda nau- } \\
\text { plii }\end{array}$ & 0.59 \\
\hline & & & Clupeidae-Apendicularia & 0.59 \\
\hline & & & Gobiidae-Amphipoda & 0.49 \\
\hline \multirow[t]{10}{*}{ Guadiana } & Clupeidae-Annelida larvae & 0.39 & Clupeidae-Cumacea & 0.47 \\
\hline & Clupeidae-Copepodites & 0.39 & Clupeidae-Mysidacea & 0.42 \\
\hline & $\begin{array}{l}\text { Clupeidae-Pelecypoda lar- } \\
\text { vae }\end{array}$ & 0.39 & Clupeidae-Amphipoda & 0.47 \\
\hline & Clupeidae-Hydromedusae & 0.40 & Gobiidae-Salinity & 0.51 \\
\hline & Clupeidae-Chaetognata & 0.49 & Atherinidae-Temperature & $-0.144^{\mathrm{a}}$ \\
\hline & Clupeidae-Mysidacea & 0.51 & $\begin{array}{l}\text { Athernidae-Polychaeta lar- } \\
\text { vae }\end{array}$ & 0.58 \\
\hline & Clupeidae-Apendicularia & 0.54 & & \\
\hline & Gobiidae-Cumacea & 0.37 & & \\
\hline & Gobiidae-Mysidacea & 0.43 & & \\
\hline & Blennidae-Ostracoda & 0.35 & & \\
\hline
\end{tabular}

This hypothesis could account for the unexplained portion of the variance in the models calculated and should be tested both in experimental conditions and in situ.

The larval abundance distribution in both estuaries considered in this study also correlated significantly with the abundance of several taxa referred in the literature as invertebrate predators of fish eggs and larvae (see [3] for a review). The co-occurrence of predators and larvae might constitute a trophic advantage for predators and potentially increase their predatory efficiency on fish larvae $[31,58]$. On the other hand, significant positive correlations could be due to similar patterns of feeding [2] or to comensalism [8]. In fact, hydromedusae with fish eggs and larvae inside the manubrium occurred in a number of samples. Moller [49] and van der Veer [77] reported similar occurrences. Nonetheless, it is not possible to exclude the hypothesis that feeding was stimulated by the over-concentration of the sample in the cod-end of the net. However, Moller [49] and Suthers and Frank [72] stressed the predatory potential of those taxa based on negative correlations between the abundance of predators and prey. Frank and Leggett [32] criticised these evidences and claimed that the inverse relationships could reflect the adaptive responses of larvae or the historical impact of predation on the reproductive behaviour of adults. Moreover, despite their importance in several ecosystems [2, 46, 49, 57, 65], the abundance of hydromedusae and chaetognats were poorly correlated with the abundance of fish larvae $(r<0.50)$. The massive occurrence of hydromedusae in some stations resulted in the rapid clogging of the net. This could have contributed to the underestimation of the densities of other zooplankters, thus reducing the number of significant correlations. 


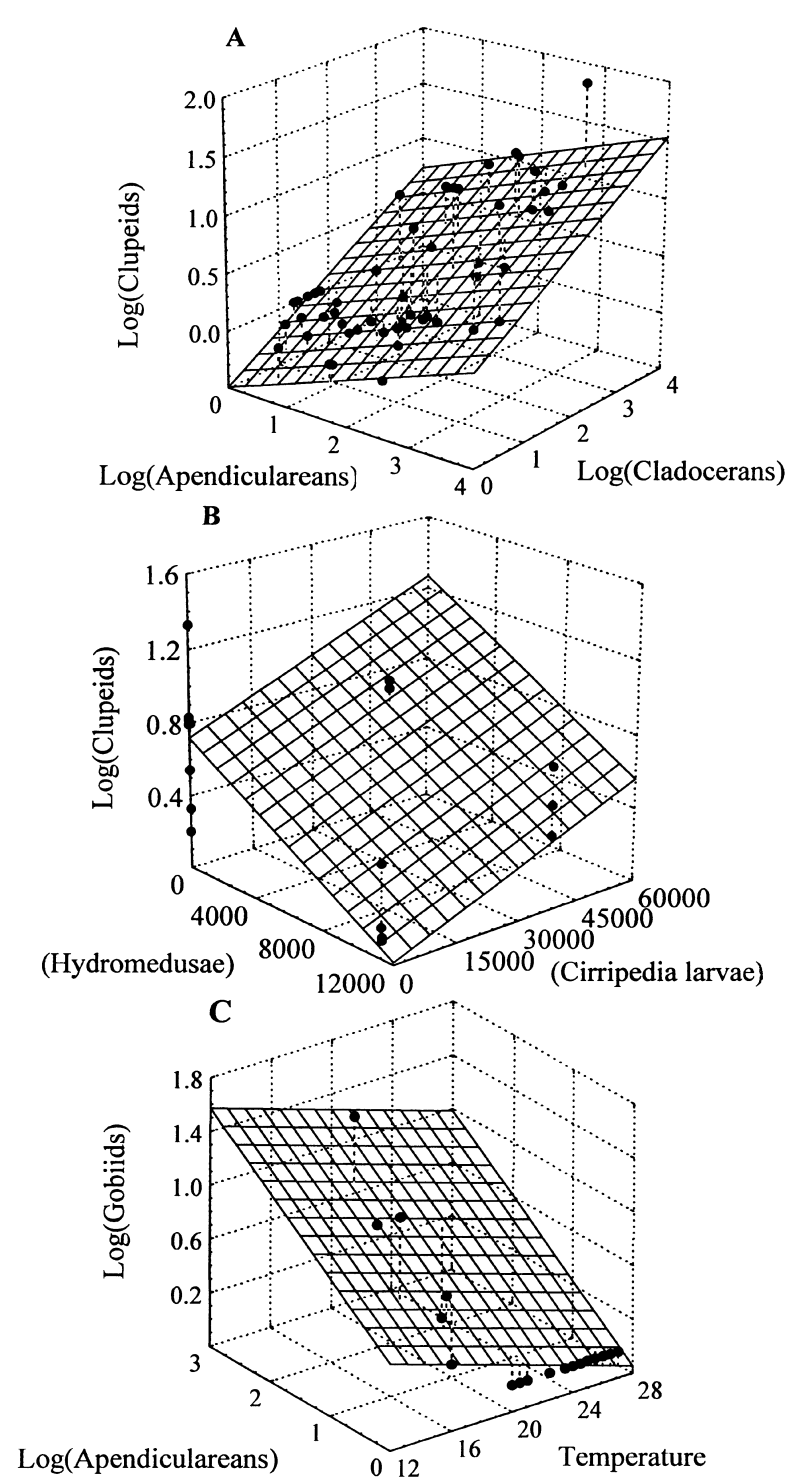

Figure 7. Surface plots for the relationships between fish larvae abundance and correlated variables in the Mira and Guadiana estuaries (A, clupeids/diel sampling, river Mira; B, clupeids/spatial sampling, river Guadiana; C, gobiids/spatial sampling, river Mira) (see table $I V$ for equations).

Our results (cf. tables III, IV) suggest that predation in association with temperature are the major factors controlling the abundance distribution of fish larvae. Nevertheless, significant correlations might reflect the similar feeding strategies or the collection method used for both larvae and their invertebrate predators. Interestingly, hydromedusae were not significant covariates in the equations, although they were very representative taxa of the mesozooplankton commu- nity, especially in the Mira estuary ( $>40 \%$ of total abundance, cf. table II). Most of those organisms were less than $80 \mathrm{~mm}$ in diameter and therefore their impact on the larvae should be considered [65]. However, the occurrence of hydromedusae and fish larvae could be mutually exclusive, i.e. it could reflect adaptive responses of fish larvae and adults to aggregations of potential predators [32]. Nevertheless, some of the associations of animals in the net could be coincidental, depending on the length of the tow, and the organisms may have not been together in the water column.

\subsection{Larval condition}

Temperature was negatively correlated with RNA/DNA ratios when integrated in multiple regressions. This could be due to the reduced activity of ribosomes at lower temperatures, and the higher content of RNA required to maintain the same activity level [11] whereas the DNA content stays unchanged. In contrast to our findings, McGurk et al. [48] found no relationship between RNA/DNA ratios and prey concentration or temperature.

The nutritional condition of fish larvae correlated more significantly with indicators of potential prey abundance. Better feeding conditions in terms of prey density and food type usually determine enhanced growth rates and nutritional condition [5, 9, 14, 45]. However, in order to estimate prey densities, it is necessary to make a preliminary study of the type of organisms consumed by larvae. In this study, results published elsewhere $[7,17,20,22,27,40,54]$ were used to establish a compatible method of collection (cf. Materials and Methods). As a result, a reasonable number of organisms, considered as potential prey, were found in most of the samples collected. Moreover, the number of significant correlations obtained herein supports the methodology chosen for studying microzooplankton.

Significant correlations obtained between fish larvae condition and the abundance of potential predators (cf. tables VI, VII) could be related to predation on energyrich larvae or larvae in poorer condition. In the first case, the negative correlations would reflect the removal of larvae with higher RNA/DNA ratios. On the other hand, the diminished ability of larvae in poorer condition to escape predators, feed and compete for food items accelerates the starvation process and could be responsible for the positive correlations. Frank and Leggett [32] argued that the spawning strategy of fish avoids areas of higher predator abundance, and criticised the methods based on simultaneous collection of larvae and invertebrate predators. Herein, the exclusive occurrence of hydromedusae in some stations of the Mira estuary might be an example of the afore- 
Table IV. Regression models obtained for ichthyoplankton abundance vs. relevant abiotic/biotic variables. S and D denote spatial and diel sampling, respectively. $n$, Sampling size. A, apendiculareans; C, copepodites; CL, cladocerans; CLA, cladocerans (> 500 mm); CUM, cumaceans; $\mathrm{HH}$, hydromedusae $(>500 \mu \mathrm{m})$; I, isopods; Q, chaetognats; T, temperature; TA, thaliaceans. All regressions significant: $* * *, P<0.001$.

\begin{tabular}{|c|c|c|c|c|}
\hline & Model & $n$ & $R^{2}$ & $\mathrm{~F}$ \\
\hline \multirow[t]{3}{*}{$\mathrm{Mira}_{\mathrm{S}}$} & {$[$ Blennids $]=-0.108+0.479(\mathrm{Q})-0.012(\mathrm{TA})$} & 40 & 0.931 & $249.7 * * *$ \\
\hline & {$[$ Gobiids $]=9.713-0.04(\mathrm{~T})+0.189(\mathrm{~A})$} & 32 & 0.739 & $41.09 * * *$ \\
\hline & $\log [$ Gobiids $]=0.884-0.037(\mathrm{~T})+0.377 \cdot \log (\mathrm{A})$ & 32 & 0.631 & $24.77 * * *$ \\
\hline \multirow[t]{3}{*}{$\operatorname{Mira}_{\mathrm{D}}$} & $\log [$ Clupeids $]=-0.704+0.227 \cdot \log (\mathrm{I})+0.368 \cdot \log (\mathrm{CLA})$ & 52 & 0.559 & $31.06 * * *$ \\
\hline & $\log [$ Clupeids $]=0.354-0.052(\mathrm{~T})+0.222 \cdot \log (\mathrm{I})+0.324 \cdot \log (\mathrm{CL})$ & 52 & 0.575 & $21.64 * * *$ \\
\hline & $\log [$ Clupeids $]=0.493+0.199 \cdot \log (\mathrm{A})+0.305 \cdot \log (\mathrm{CLA})$ & 52 & 0.588 & $35.02 * * *$ \\
\hline \multirow[t]{2}{*}{ Guadiana $_{\mathrm{s}}$} & $\log [$ Clupeids $]=-0.155+0.293(\mathrm{HH})+7.5 \cdot 10^{-5}(\mathrm{C})$ & 56 & 0.787 & $97.70 * * *$ \\
\hline & $\log [$ Clupeids $]=0.024+0.22 \cdot \log (\mathrm{Q})$ & 74 & 0.315 & $33.05 * * *$ \\
\hline
\end{tabular}

mentioned strategy. However, other taxa of potential predators correlated significantly with larval condition and integrated the empirical models calculated. Few studies have dealt simultaneously with field-caught fish larvae and their potential predators [3]. Therefore, the influence of experimental conditions [56] and the difficulty of studying natural mortality caused by predation, because different taxa can act on larvae and might not be collected by the gear, are among the most common criticisms of predation experiments.

In this study, the variability of larval nutritional condition seems related more closely to prey availability than with the other variables. Buckley et al. [9] also presented a number of equations relating indices of condition of cultivated Ammodytes americanus larvae with temperature and prey density. Conversely, McGurk et al. [48] and Canino [15] showed that the influence of prey availability on the variability of RNA/DNA ratios was negligible and that predation would be an additional and seasonal factor of importance. Recently, Chícharo [18] presented a polynomial equation including temperature and the density of chaetognats, which accounted for $80 \%$ of the variance of RNA/DNA ratios of Sardina pilchardus larvae.

Frank [30] pointed out that the use of a single net to sample both zooplankton and fish larvae might ob-

Table V. Nutritional condition of fish larvae (RNA/DNA ratios) from the Mira and Guadiana estuaries (March-September 1997). $n$, Number of individuals analysed. Values are mean \pm standard error.

\begin{tabular}{lccccc}
\hline & \multicolumn{2}{l}{ Mira } & & \multicolumn{2}{c}{ Guadiana } \\
\cline { 2 - 3 } \cline { 5 - 6 } & $n$ & Ratio & & $n$ & Ratio \\
\hline Clupeidae & 17 & $5.54 \pm 0.77$ & & 37 & $8.15 \pm 0.65$ \\
Gobiidae & 80 & $5.54 \pm 0.38$ & & 69 & $3.79 \pm 0.32$ \\
Blennidae & 22 & $2.98 \pm 0.36$ & & 63 & $3.42 \pm 0.31$ \\
Atherinidae & 14 & $4.84 \pm 0.87$ & & 34 & $4.20 \pm 0.42$
\end{tabular}

scure eventual ecological links. Herein, two nets with different mesh-size were used to overcome sampling bias. Moreover, according to Fortier and Leggett [29], simple correlation analyses are insufficient to study the relationships between fish larvae and zooplankton. However, in this study, the information obtained from correlation analysis is presented as a contribution to assess the relative importance of variables in determining the general distribution and the nutritional condition of fish larvae. These results should be taken into consideration in future work in these estuaries or similar temperate ecosystems.

In summary, the distribution of fish larvae seems conditioned by temperature and predation pressure, whereas their nutritional condition is dependent on

Table VI. Significant Spearman correlation coefficients $(r)$ obtained for the relationships between ichthyoplankters nutritional condition (pooled data) and several taxa $(* * *, P<0.001)$.

\begin{tabular}{lllc}
\hline River & Family & Taxa & $r$ \\
\hline Guadiana & Clupeidae & Copepod nauplii & $0.53 * * *$ \\
& & Cumacea & $0.63 * * *$ \\
& Mysidacea & $0.70^{* * *}$ \\
& Amphipoda & $0.52 * * *$ \\
& \multirow{2}{*}{ Blennidae } & Dinoflagellata & $0.44 * * *$ \\
& & Annelid larvae & $-0.39 * * *$ \\
& Copepod nauplii & $0.55^{* * *}$ \\
& Decapod nauplii & $-0.46^{* * *}$ \\
& Pelecypoda larvae & $-0.40^{* * *}$ \\
& Hydromedusae & $0.62 * * *$ \\
& Cladocera & $0.39 * * *$ \\
& Cumacea & $0.56 * * *$ \\
& Gobiidae & Amphipoda & $0.63 * * *$ \\
& & Decapoda & $0.60 * * *$ \\
& &
\end{tabular}



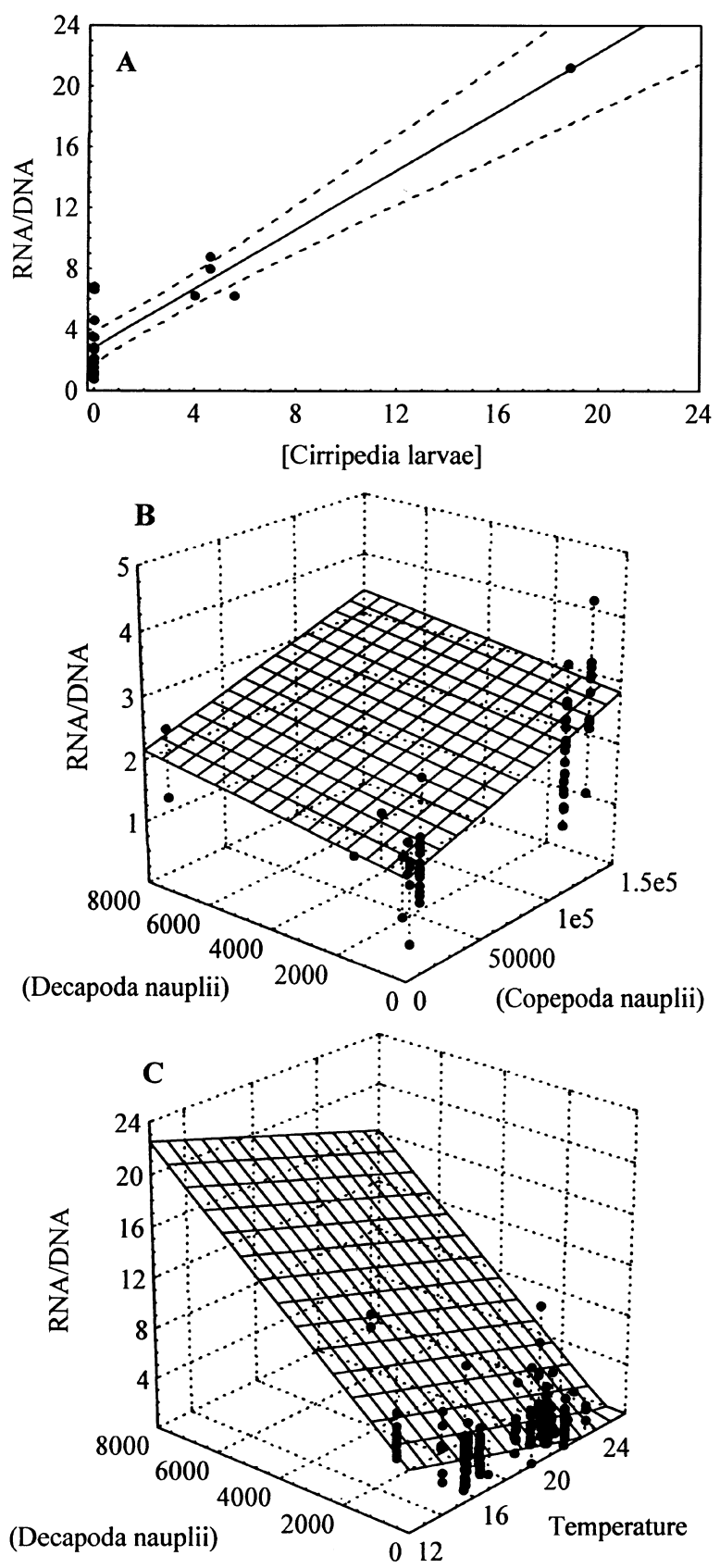

Figure 8. Scatterplots and surface plots for the relationships between the nutritional condition of fish larvae and correlated variables (see table VII for equations) in the Mira and Guadiana estuaries (A, clupeids, river Mira; B, blennids, river Guadiana; and C, clupeids, river Guadiana).

temperature and prey availability. These latter relationships are further controlled by predation, through its effect on larval mortality. The multiple linear regres- sions obtained herein for density distribution $\left(R^{2} \geq 0.315\right)$ and larval condition $\left(R^{2} \geq 0.431\right)$ seem to corroborate these hypotheses. Considering the issues of accuracy and precision aforementioned, our analyses are intended to be indicative of general trends and relative importance of environmental and biological factors. In future studies, both sample number and frequency should be increased together with the use of unconventional statistical analysis (e.g. multiple nonlinear estimations or generalised additive models). This will provide further insight into the mechanisms that regulate fish early-life history stages and recruitment.

\section{Acknowledgments}

This work was funded by Programa PRAXIS XXI (ref 3/3.2/CA/1981/95). E. Esteves benefited from a grant from Programa PRAXIS XXI (ref. BM/8427/96). Partial support for sampling in the Guadiana estuary was provided by Programa INTERREG II (ref. 15/REG II/2/96). This manuscript benefited from the comments and suggestions of Dr Graham Pierce (University of Aberdeen) and two anonymous referees.

\section{REFERENCES}

[1] Antunes M.M., Cunha P.L., Duarte A.P., Mendonça E.P., Ria de Alvor as a spawning place and a nursery ground, J. Fish Biol. 33 (Suppl. A) (1988) 185-190.

[2] Baier C.T., Purcell J.E., Trophic interactions of chaetognats, larval fish, and zooplankton in the South Atlantic Bight, Mar. Ecol. Prog. Ser. 146 (1997) 43-53.

[3] Bailey K.M., Houde E.D., Predation on eggs and larvae of marine fishes and the recruitment problem, Adv. Mar. Sci. 25 (1989) 1-83.

[4] Bain M.B., Finn J.T., Booke H.E., Streamflow regulation and fish community structure, Ecology 69 (1988) 382-392.

[5] Battini M.A., Alonso M.F., Cussac V.E., Growth and nutritional condition of the larvae of Odontesthes microlepidotus (Atherinidae): an experimental approach, Env. Biol. Fish. 42 (1995) 391-399.

[6] Bergeron J.P., Nucleic acids in ichthyoplankton ecology: a review, with emphasis on recent advances for new perspectives, J. Fish Biol. 51 (Suppl. A) (1997) 284-302.

[7] Blaxter J.H.S., Hunter J.R., The biology of clupeoid fishes, Adv. Mar. Biol. 20 (1982) 1-223.

[8] Brodeur R.D., In situ observations of the association between juvenile fishes and scyphomedusae in the Bering Sea, Mar. Ecol. Prog. Ser. 163 (1998) 11-20.

[9] Buckley L.J., Turner S.I., Halavik T.A., Smigielski A.S., Drew S.M., Laurence G.C., Effects of temperature and food availability on growth, survival, and RNA-DNA ratio of larval sand lance (Ammodytes americanus), Mar. Ecol. Prog. Ser. 15 (1984) 91-97.

[10] Bulow F., RNA-DNA ratios as indicators of recent growth rates of a fish, J. Fish. Res. Board Can. 27 (1970) 2343-2349.

[11] Bulow F., RNA-DNA ratios as indicators of growth in fish: A review, in: Summerfelt R.C., Hall G.E. (Eds.), Age and 
Table VII. Regression models obtained for RNA/DNA ratios vs. relevant abiotic/biotic variables. $n$, Sampling size (AN, annelid larvae; C, copepodites; CC, copepod nauplii; CIL, ciliates; CR, cirriped nauplii; CUM, cumaceans; D, decapod nauplii; DD, decapod (zoea/mysis); DN, dinoflagellates; HH, hydromedusae (> $500 \mathrm{~mm}$ ); PL, bivalve larvae; PREY, pooled prey; T, temperature. All regressions significant: ***, $P<0.001)$.

\begin{tabular}{|c|c|c|c|c|}
\hline & Model & $n$ & $R^{2}$ & $\mathrm{~F}$ \\
\hline \multicolumn{5}{|l|}{ Mira } \\
\hline \multirow[t]{4}{*}{ Clupeidae } & RNA/DNA $=58.608+0.0053(\mathrm{D})-3.227 \cdot \mathrm{T}-0.00003(\mathrm{C})+0.00029(\mathrm{CC})$ & 17 & 0.955 & $64.26^{* * *}$ \\
\hline & RNA/DNA $=7.55-0.0004(\mathrm{CR})-3.80 \cdot \mathrm{T}+0.0061(\mathrm{D})$ & 16 & 0.948 & $73.39 * * *$ \\
\hline & RNA/DNA = $2.849+0.972(\mathrm{CR})$ & 18 & 0.859 & $97.34 * * *$ \\
\hline & $\mathrm{RNA} / \mathrm{DNA}=4.59+0.001(\mathrm{CC})+0.00012(\mathrm{PL})-7 \cdot 10^{-5}(\mathrm{PREY})$ & 16 & 0.732 & $10.93 * * *$ \\
\hline \multicolumn{5}{|l|}{ Guadiana } \\
\hline \multirow[t]{2}{*}{ Clupeidae } & $\mathrm{RNA} / \mathrm{DNA}=10.28+0.0022(\mathrm{DD})-0.449 \cdot \mathrm{T}$ & 35 & 0.639 & $28.28 * * *$ \\
\hline & RNA/DNA $=0.369+0.00259(\mathrm{DD})+0.0092(\mathrm{D})$ & 33 & 0.654 & $28.34 * * *$ \\
\hline \multirow[t]{3}{*}{ Blennidae } & RNA/DNA $=1.642+0.0002(\mathrm{DN})+5 \cdot 10^{-6}(\mathrm{CC})$ & 60 & 0.431 & $21.59 * * *$ \\
\hline & RNA/DNA $=1.638+0.0109(\mathrm{HH})-0.296(\mathrm{CUM})$ & 60 & 0.436 & $22.00 * * *$ \\
\hline & RNA/DNA $=1.654+4 \cdot 10^{-6}(\mathrm{CC})+0.002(\mathrm{HH})$ & 60 & 0.434 & $21.82 * * *$ \\
\hline Gobiidae & RNA/DNA $=0.313+0.0027(\mathrm{AN})+0.00051(\mathrm{C})+0.0011(\mathrm{D})$ & 60 & 0.608 & $13.97 * * *$ \\
\hline
\end{tabular}

Growth of Fish, Iowa State University Press, Ames, Iowa, 1987, pp. 45-64.

[12] Buskey E.J., Annual pattern of micro- and mesozooplankton abundance and biomass in a subtropical estuary, J. Plankton Res. 15 (1993) 907-924.

[13] Caldarone E.M., Buckley L.J., Quantitation of DNA and RNA in crude tissues extracts and flow injection analysis, Anal. Biochem. 199 (1991) 137-141.

[14] Canino M.F., Effects of temperature and food availability on growth and RNA/DNA ratios of walleye pollock Theragra chalcogramma (Pallas) eggs and larvae, J. Exp. Mar. Biol. Ecol. 175 (1994) 1-16.

[15] Canino M.F., Nucleic acid contents and growth of first-feeding walleye pollock larvae in response to prey densities typical of sub-Artic ecosystems, J. Fish Biol. 51 (1997) 41-52.

[16] Chícharo L.M.Z., Contribuição para o estudo do ictioplâncton no estuário do Guadiana, Graduation thesis, University of Algarve, Faro, 1988, 75 p.

[17] Chícharo M.A., Starvation percentages in field caught Sardina pilchardus larvae off southern Portugal, Sci. Mar. 61 (1997) 507-516.

[18] Chícharo M.A., Nutritional condition and starvation in Sardina pilchardus (L.) larvae off southern Portugal compared with some environmental factors, J. Exp. Mar. Biol. Ecol. 225 (1998) 123-137.

[19] Conover W.J., Practical Nonparametric Statistics, 2nd ed., John Wiley \& Sons, New York, 1980, 493 p.

[20] Conway D.V.P., Coombs S.H., Férnandez de Puelles M.L.F., Tranter P.R.G., Feeding of larval sardine, Sardina pilchardus (Walbaum), Bol. Inst. Esp. Oceanogr. 10 (1994) 165-175.

[21] Costa M.J., Bruxelas A., Rosado D., Ictiofauna do estuário do Mira, abundância e diversidade, $2^{\circ}$ Congresso sobre o Alentejo, Beja, I, 1987, pp. 226-230.

[22] Crecco V.A., Blake M.M., Feeding ecology of coexisting larvae of American shad and blueback herring in the Connecticut River, Trans. Am. Fish. Soc. 112 (1983) 498-507.

[23] Crecco V.A., Savoy T.F., Effects of fluctuations in hydrographic conditions on year-class strength of American shad
(Alosa sapidissima) in the Connecticut River, Can. J. Fish. Aquat. Sci. 41 (1984) 1216-1223.

[24] Crecco V.A., Savoy T.F., Effects of biotic and abiotic factors on growth and relative survival of young American shad, Alosa sapidissima, in the Conneticut River, Can. J. Fish. Aquat. Sci. 42 (1985) 1448-1640.

[25] DeVries D.R., Stein R.A., Complex interactions between fish and zooplankton: quantifying the role of an open-water planktivore, Can. J. Fish. Aquat. Sci. 49 (1992) 1216-1227.

[26] Esteves E., Pina T., Chícharo M., Coelho M.L., Andrade J.P., Comparison of RNA/DNA ratios obtained with two methods for nucleic acid quantification in gobiid larvae, J. Exp. Mar. Biol. Ecol. 245 (2000) 43-55.

[27] Ferreira P.L., Ré P., Feeding of larval anchovy, Engraulis encrasicolus (L.), in the Mira Estuary (Portugal), Port. Zool. 2 (1993) 25-37.

[28] Fives J.M., Blennidae of the North Atlantic (revised), Identification sheets on fish eggs and larvae, ICES 172 (1986) 6 p.

[29] Fortier L., Leggett W.C., Small-scale covariability in the abundance of fish larvae and their prey, Can. J. Fish. Aquat. Sci. 41 (1984) 502-512.

[30] Frank K.T., Independent distribution of fish larvae and their prey: natural paradox or sampling artefact, Can. J. Fish. Aquat. Sci. 45 (1988) 48-59.

[31] Frank K.T., Leggett W.C., Environmental regulation of growth rate, efficiency and swimming performance in larval capelin (Mallotus villosus) and its application to the match/mismatch hypothesis, Can. J. Fish. Aquat. Sci. 39 (1982) 691-699.

[32] Frank K.T., Leggett W.C., Reciprocal oscillations in densities of larval fish and potential predators: a reflection of present or past predation, Can. J. Fish. Aquat. Sci. 42 (1985) 1841-1849.

[33] Hjort J., Fluctuation in the great fisheries of northern Europe. Viewed in the light of biological research, Rapp. P.-v. Reun. Cons. Perm. Int. Explor. Mer 20 (1914) 1-228.

[34] Hjort J., Fluctuations in year classes of important food fishes, J. Cons. Perm. Int. Explor. Mer 1 (1926) 5-38.

[35] Holmes R.H.A., Henderson P.A., High fish recruitment in the 
Severn Estuary: the effect of a warm year? J. Fish Biol. 36 (1990) 961-963.

[36] Houde E.D., Micro- and fine-scale biology, in: Rothshild B.J., Rooth C.G.H. (Eds.), Fish Ecology III. A foundation for REX - A Recruitment Model, Technical Report No. 82008, University of Miami, Miami, 1982, pp. 96-122.

[37] Houde E.D., Patterns and trends in larval-stage growth and mortality of teleost fish, J. Fish Biol. 51 (Suppl. A) (1997) $52-83$.

[38] Hugie D.M., Dill L.M., Fish and game: a game theoretic approach to habitat selection by predators and prey, J. Fish Biol. 45 (Suppl. A) (1994) 151-170.

[39] Hunter J.R., Report on a colloquium on larval fish mortality studies and ther relation to fishery research. January 1975, Natl. Oceanic Atmos. Adm. Tech. Rep. NMFS CIRC. 395 (1976) $5 \mathrm{p}$.

[40] Hunter J.R., Feeding ecology and predation of marine fish larvae, in: Lasker R. (Ed.), Marine Fish Larvae. Morphology, Ecology and Relation to Fisheries, Washington Sea Grant Program, Washington, 1981, pp. 33-79.

[41] Hunter J.R., Thomas G.L., Effect of prey distribution and density on the searching and feeding behaviour of larval anchovy Engraulis mordax Girard, in: Blaxter J.H.S. (Ed.), The Early Life History of Fish, Springer-Verlag, New York, 1974, pp. 559-574.

[42] Knox G.A., Estuarine ecosystems: a systems approach, vol. 1, CRC Press Inc., Boca Raton FL, 1986, 289 p.

[43] Lasker R., Field criteria for survival of anchovy larvae: the relation between inshore chlorophyll maximum layers and successful first feeding, Fish. Bull. U. S. 73 (1975) 453-462.

[44] Laurence G.C., Nutrition and trophodynamics of larval fish review, concepts, strategic recommendations and opinions, in: Rothshild B.J., Rooth C.G.H. (Eds.), Fish Ecology III. A foundation for REX - A Recruitment Model, Technical Report no. 82008, University of Miami, Miami, 1982, pp. 123-171.

[45] Martin F.D., Wright D.A., Means J.C., Setzler-Hamilton E.M., Importance of food supply to nutritional state of larval striped bass in the Potomac river estuary, Trans. Am. Fish. Soc. 114 (1985) 137-145.

[46] Matsakis S., Conover R.J., Abundance and feeding of medusae and their potential impact as predators on other zooplankton in Bedford Basin (Nova Scotia, Canada) during Spring, Can. J. Fish. Aquat. Sci. 48 (1991) 1419-1430.

[47] Mclusky S.D., The Estuarine Ecosystem, Blackie, Glasgow and London, 1989, $215 \mathrm{p}$.

[48] McGurk M.D., Warburton H.D., Galbraith M., Kusser W.C., RNA-DNA ratio of herring and sand lance larvae from Port Moller, Alaska. Comparison with prey concentration and temperature, Fish. Oceanogr. 1.3 (1992) 193-207.

[49] Moller H., Reduction of a larval herring population by jellyfish predator, Science 224 (1984) 621-622.

[50] Newell G.E., Newell R.C., Marine Plankton, a Practical Guide, 5th ed., Hutchinson of London, London, 1963, 244 p.

[51] Omori M., Ikeda T., Methods in Marine Zooplankton Ecology, Krieger Publishing Company, Florida, 1992, 279 p.

[52] Palmer C.J., Culley M.B., The egg and early life stages of the sandsmelt, Atherina presbyter Cuvier, J. Fish Biol. 24 (1984) 537-544.

[53] Palomera I., Spawning of anchovy Engraulis encrasicolus in the Northwestern Mediterranean relative to hydrographic features in the region, Mar. Ecol. Prog. Ser. 79 (1992) 215-223.

[54] Pepin P., Penney R.W., Patterns of prey size and taxonomic composition in larval fish: are there general size-dependent models? J. Fish Biol. 51 (Suppl. A) (1997) 84-100.

[55] Pestana M.G., Manancial ibérico-atlântico de sardinha (Sardinha pilchardus, Walb.) sua avaliação e medidas de gestão, Unpubl. dissertation, Instituto Nacional de Investigação Científica, Lisboa, 1989, 192 p.

[56] Peterson C.H., Black R., An experimentalist's challenge: when artefacts of intervention interact with treatments, Mar. Ecol. Prog. Ser. 11 (1994) 289-297.

[57] Purcell J.E., Soft-bodied zooplankton predators and competitors of larval herring (Clupea harengus pallasi) at herring spawning grounds in British Columbia, Can. J. Fish. Aquat. Sci. 48 (1990) 505-515.

[58] Purcell J.E., Grover J.J., Predation and food limitation as causes of mortality in larval herring at a spawning ground in British Columbia, Mar. Ecol. Prog. Ser. 59 (1990) 55-61.

[59] Ré P., Ictioplâncton da região central da costa portuguesa e do estuário do Tejo. Ecologia da postura e da fase planctónica de Sardina pilchardus (Walbaum, 1792) e de Engraulis encrasicolus (Linné, 1758),Ph.D. thesis (Ed.), Faculty of Sciences University of Lisbon, Lisbon, 1984, 425 p.

[60] Ré P., Farinha A., Meneses I., Anchovy spawning in Portuguese estuaries (Engraulis encrasicolus, Pisces: Engraulidae), Cybium 7 (1983) 29-38.

[61] Robinson C.L., Bain M.B., Determinants of estuarine nursery habitat for fish, in: Magoon O.T., Converse H., Miner D., Tobin T., Clark D. (Eds.), Coastal Zone '89, vol. 2, American Society of Civil Engineers, New York, 1989, pp. 997-1010.

[62] Russell F.S., The Eggs and Planktonic Stages of British Marine Fishes, Academic Press, London, 1976, 524 p.

[63] Saville A., Clupeiodae, Identification sheets on fish eggs and larvae, ICES 1 (1964) 5.

[64] Scheidegger K.J., Bain M.B., Larval fish distribution and microhabitat use in free-flowing and regulated rivers, Copeia 1995 (1995) 125-135.

[65] Schneider G., Behrends G., Population dynamics and the trophic role of Aurelia aurita medusae in the Kiel Bight and western Baltic, ICES J. Mar. Sci. 51 (1994) 359-367.

[66] Sinclair M., Marine Populations. An Essay on Population Regulation and Speciation, Books in Recruitment Fishery Oceanography, Washington Sea Grant, Washington, 1988, $252 \mathrm{p}$.

[67] Sinclair M., Iles T.D., Atlantic herring (Clupea harengus) distributions in the Gulf of Maine-Scotian shelf area in relation to oceanographic features, Can. J. Fish. Aquat. Sci. 42 (1985) 872-880.

[68] Smith D.L., A Guide to Marine Coastal Plankton and Marine Invertebrate Larvae, Kendall/Hunt Company, Dubuque-Iowa, 1977, $161 \mathrm{p}$.

[69] Snedecor G., Cochran W., Statistical Methods, Iowa State University Press, Ames-Iowa, 1982, 503 p.

[70] SPSS Inc., SPSS for Windows Release 10.0.5. Standard version, (Software package and Manual), SPSS Inc., Chicago, 1999.

[71] Stein R.A., DeVries D.R., Dettmers J.M., Food-web regulation by a planktivore: exploring the generality of the trophic cascade hypothesis, Can. J. Fish. Aquat. Sci. 52 (1995) 2518-2526.

[72] Suthers I.M., Frank K.T., Zooplankton biomass gradient off south-western Nova Scotia: nearshore ctenophore predation or hydrographic separation? J. Plankton Res. 12 (1990) 831-850.

[73] Taggart C.T., Leggett W.C., Short-term mortality in postemergent larval capelin Mallotus villosus. II. Importance of 
food and predator density, and density-dependence, Mar. Ecol. Prog. Ser. 41 (1987) 219-229.

[74] Thiel R., Sepúlveda A., Kafemann R., Nellen W., Environmental factors as forces structuring the fish community of the Elbe Estuary, J. Fish Biol. 46 (1995) 47-69.

[75] Todd C.D., Laverack M.S., Coastal Marine Zooplankton. A Practical Manual for Students, Cambridge University Press, Cambridge, 1991, $159 \mathrm{p}$.

[76] Turner T.F., Trexler J.C., Miller G.L., Toyer K.E., Temporal and spatial dynamics of larval and juvenile fish abundance in a temperate floodplain river, Copeia 1994 (1994) 174-183.
[77] van der Veer H.W., Impact of coelenterate predation on larval plaice Pleuronectes platessa and flounder Platichthys flesus in the western Wadden Sea, Mar. Ecol. Prog. Ser. 25 (1985) 229-238.

[78] Wyatt T., Some effects of food density on the growth and behaviour of plaice larvae, Mar. Biol. 14 (1972) 210-216.

[79] Zar J.H., Biostatistical Analysis, 3rd ed., Prentice Hall International Editions, NJ, 1996. 